\title{
A Tribute to Jackie Kirk Activist, Academic and Champion of Girls
}

\author{
Claudia Mitchell and Jacqui Reid-Walsh
}

\section{$\cos 80$}

In September, 2008, a month after Jackie Kirk's untimely death in Afghanistan, Claudia organized a special gathering of her class on Women, Education and Development at McGill University. The gathering was made up of Claudia's graduate students, a group of scholars, friends of Jackie's, her parents and other relatives. The seminar was dedicated to Jackie - looking back, but also looking ahead to what could be done to keep alive the spirit and energy of her work across so many different aspects of education in post-conflict settings, women teachers as peacebuilders and girls' education. Similarly, this issue offers a remembrance, a celebration, and a moving forward in relation her life and work.

Jackie was a driving force in the conceptualization of the journal, and although she didn't live to see the first issue come out, she continues to be a source of inspiration. Indeed, this inspiration has helped lead us to an award for excellence. Just as we were putting this issue together we learned from our publisher, Vivian Berghahn, that GHS had been named the 2010 recipient of the PROSE award from the Association of American Publishers for Professional and Scholarly Publications. The award is for the best new journal in the Social Sciences and Humanities.

This issue of GHS is only one of many tributes to the memory of Jackie. The Comparative and International Education Society (CIES) now offers the Jackie Kirk Outstanding Book award each year to an author in recognition of new scholarship in an area close to Jackie's work. This award is funded by CIES, the International Rescue Committee (IRC) — an emergency relief and rebuilding organization with which Jackie was working when she was killed—and Jackie's husband, Dr Andy Kirk. The Faculty of Education, McGill University, where Jackie completed her PhD, makes available an annual award to a graduate student working in one of the areas of scholarship linked to her work, thanks to the generosity of Andy along with that of the McConnell Foundation. Zainul Sajan Virgi, one of the contributors to this issue, was the first recipient of this award for her work with girls in Mozambique. 
When we issued a call for papers for this special issue, we received inquiries and follow up submissions dealing with girlhood in many different parts of the world. This is something that speaks both to the reach of Jackie's work and also to the global context of issues related to girlhood. Since there were too many submissions for just one issue, several of these will appear in the next issue of GHS.

We thank all the contributors and especially Dr Fiona Leach, a member of the editorial board of GHS, who joined us as guest editor of this issue.

Those of us engaged with GHS continue to be inspired by Jackie's life and achievements. 